\title{
Milk fatty acid profile of cows under the influence of alpine hypoxia and high mountainous forage quality ${ }^{*}$
}

\author{
F. Leiber ${ }^{1}$, M.R.L. Scheeder, H.-R. Wettstein and M. Kreuzer \\ Institute of Animal Science, Animal Nutrition, Swiss Federal Institute of Technology (ETH) Zurich \\ ETH Centre/LFW CH-8092 Zurich, Switzerland
}

\begin{abstract}
Influences of high alpine hypoxia, of an alpine forage-only diet and of a typical alpine feed quality on milk fat composition of dairy cows were tested at two altitudes (400 and $2000 \mathrm{~m}$ a.s.l.) with two hay types one originating from lowlands one from highlands and fed at both altitudes. Hypoxia caused reduced proportions of n-3 fatty acids, particularly $\alpha$-linolenic acid, in milk fat but the alpine feeding regime increased proportions of all n-3 fatty acids and CLA to a much greater extent. Feeding alpine hay decreased the proportion of the saturated fatty acids in milk fat.
\end{abstract}

KEY WORDS: altitude, conjugated linoleic acid, omega-3 fatty acids, dairy cows

\section{INTRODUCTION}

Milk products originating from high alpine grazing of cows seem to provide an extraordinarily high proportion of $t 9 c 11$-conjugated linoleic acid (CLA) and n-3 polyunsaturated fatty acids (PUFA; Kraft et al., 2003) making these products functional feeds with an expected high value for human health (Hauswirth et al., 2004). However, the question remains open whether a comparable fatty acid profile can be achieved under defined environmental and feeding conditions in lowlands (Leiber et al., 2004b). To evaluate the extent to which specific and exclusive alpine conditions contribute to the effect of alpine grazing on fatty acids, an experimental design was followed, which allowed to differentiate between the influences of high alpine hypoxia and of the alpine forage quality, which both are exclusive highland phenomena (Leiber et al., 2004a) and of a typical alpine type of diet without maize and concentrates, which may also be practiced in lowland farms.

\footnotetext{
* Supported by a Grant of the Federal Office for Agriculture of Switzerland, Berne

${ }^{1}$ Corresponding author: e-mail: florian.leiber@inw.agrl.ethz.ch
} 


\section{MATERIAL AND METHODS}

Four treatment groups consisted of six early to mid-lactating dairy cows each. A first group (AA) was kept tethered in a barn at $2000 \mathrm{~m}$ a.s.l. and was fed only hay ad libitum. All other groups were kept tethered in a barn at $400 \mathrm{~m}$ a.s.l. Group LA was also fed hay ad libitum. As all cows were in barns and did not have to walk for feeding, it is assumed that the comparison of groups AA and LA shows mainly the influence of hypoxia. Group LP was pair-fed to group AA to evaluate the influence of a temporary anorexia assumed to occur at high altitude in group AA. Group LC was fed a usual lowland diet consisting mainly of silages $(30 \%$ maize) and, corresponding to milk yield, concentrates containing cereals and protected saturated fatty acids (SFA), thus showing the differences between an intensive lowland diet and the forage-only alpine diet. Embedded in the hay-only treatment groups AA, LA and LP was a comparison of two hay types of either alpine or lowland origin. These hays were fed in a change-over design in all three groups over three experimental periods of three weeks each. Alpine hay was less digestible and poorer in metabolizable energy, crude protein and in fat content than lowland hay. The third week of each experimental period served as sampling week. Feed samples were pooled per sampling week, milk was pooled per animal and sampling week prior to analysis. Fatty acids were analysed on a SIL-88 column $(100 \mathrm{~m} \times 0.25 \mathrm{~mm}, 0.2 \mu \mathrm{m}$; Varian Inc). More details of the experimental procedure and the statistical models used for data evaluation are extensively described in Leiber et al. (2004a).

\section{RESULTS AND DISCUSSION}

Comparison of groups AA and LA shows that high altitude caused a moderate but significant decrease of the proportions of the $n-3$ fatty acids C18:3 ( $\alpha$-linolenic acid, ALA) and C20:3 in milk fat, which consequently also reduced the sum of n-3 PUFA (Table 1). Since the intake of energy, protein and fatty acids did not differ between AA and LA, hypoxia seems to influence the milk fatty acid profile directly, but the mechanisms are not clear.

By contrast the alpine diet type caused huge shifts in the fatty acid profile as is particularly obvious from the comparison between groups LA and LC. Except C20:3n-3 all other n-3 PUFA and also CLA were higher in the hay-alone groups; ALA concentration of milk fat in LA was 2.5 times of that in LC. Since n-6 PUFA in the hay-alone groups were reduced, the proportion of n- 6 to n-3 was clearly less than half of that found in group LC. This shows that the omission of C18:1 and C18:2 input from maize and cereals and of protected SFA from the concentrates may already explain a part of the differences in fatty acid profile of cow's milk found between lowland and alpine systems (Kraft et al., 2003). 
Table 1 . Intake and milk fatty acid profile as affected by treatments ( $\mathrm{n}=18$ per group)

\begin{tabular}{|c|c|c|c|c|c|c|}
\hline & \multicolumn{4}{|c|}{ Treatment groups } & \multirow{2}{*}{ Significance } & \multirow{2}{*}{ SE } \\
\hline & AA & LA & LP & $\mathrm{LC}$ & & \\
\hline \multicolumn{7}{|l|}{ Intake } \\
\hline $\mathrm{NE}_{\mathrm{L}}{ }^{1}, \mathrm{MJ} / \mathrm{day}$ & $92.6^{b}$ & $96.1^{\mathrm{b}}$ & $87.4^{b}$ & $126.7^{\mathrm{a}}$ & $* * *$ & 4.53 \\
\hline C18:3n-3, g/day & 89.8 & 94.8 & 85.1 & 79.4 & ns & 7.07 \\
\hline total FAME, g/L milk & 40.5 & 39.5 & 40.5 & 41.6 & ns & 1.34 \\
\hline \multicolumn{7}{|l|}{ FAME composition, $\%$} \\
\hline $\mathrm{C} 4: 0$ & $3.27^{\mathrm{ab}}$ & $3.07^{\mathrm{b}}$ & $3.18^{\mathrm{b}}$ & $3.52^{\mathrm{a}}$ & $*$ & 0.097 \\
\hline C6:0 & $2.25^{\mathrm{b}}$ & $2.15^{b}$ & $2.18^{\mathrm{b}}$ & $2.42^{\mathrm{a}}$ & $*$ & 0.058 \\
\hline C8:0 & $1.26^{\mathrm{ab}}$ & $1.23^{\mathrm{b}}$ & $1.22^{\mathrm{b}}$ & $1.38^{\mathrm{a}}$ & $\dagger$ & 0.043 \\
\hline $\mathrm{C} 10: 0$ & 2.77 & 2.77 & 2.72 & 2.98 & ns & 0.132 \\
\hline $\mathrm{C} 12: 0$ & 3.24 & 3.31 & 3.13 & 3.41 & ns & 0.179 \\
\hline $\mathrm{C} 14: 0$ & 11.8 & 12.1 & 11.3 & 10.8 & ns & 0.42 \\
\hline $\mathrm{C} 16: 0$ & 34.9 & 34.4 & 34.0 & 35.0 & ns & 0.90 \\
\hline C18:0 & $7.10^{\mathrm{b}}$ & $7.57^{b}$ & $7.91^{\mathrm{ab}}$ & $9.20^{\mathrm{a}}$ & $*$ & 0.444 \\
\hline $\mathrm{C} 18: 1 t 10 / t 11$ & $1.56^{\mathrm{a}}$ & $1.51^{\mathrm{a}}$ & $1.53^{\mathrm{a}}$ & $0.96^{\mathrm{b}}$ & $* * *$ & 0.077 \\
\hline $\mathrm{C} 18: 1 c 9$ & 17.2 & 16.7 & 18.0 & 18.0 & ns & 1.08 \\
\hline$C 18: 3 n-3$ & $1.08^{b}$ & $1.27^{\mathrm{a}}$ & $1.23^{\mathrm{a}}$ & $0.44^{\mathrm{c}}$ & $* * *$ & 0.049 \\
\hline $\mathrm{C} 18: 2 c 9 t 11$ & $0.82^{\mathrm{a}}$ & $0.80^{\mathrm{a}}$ & $0.76^{\mathrm{a}}$ & $0.47^{\mathrm{b}}$ & $* * *$ & 0.042 \\
\hline$C 20: 3 n-3$ & $0.096^{\mathrm{b}}$ & $0.120^{\mathrm{a}}$ & $0.123^{\mathrm{a}}$ & $0.112^{\mathrm{ab}}$ & $*$ & 0.0070 \\
\hline C20:5n-3 & $0.111^{\mathrm{a}}$ & $0.108^{\mathrm{a}}$ & $0.097^{\mathrm{a}}$ & $0.059^{\mathrm{b}}$ & $* * *$ & 0.0063 \\
\hline $\mathrm{C} 22: 5 n-3$ & $0.113^{\mathrm{a}}$ & $0.113^{\mathrm{a}}$ & $0.102^{\mathrm{a}}$ & $0.074^{\mathrm{b}}$ & $* * *$ & 0.0059 \\
\hline$\sum n-3$ & $1.72^{\mathrm{b}}$ & $2.02^{\mathrm{a}}$ & $1.91^{\mathrm{a}}$ & $0.93^{c}$ & $* * *$ & 0.064 \\
\hline$\sum \mathrm{n}-6$ & $1.90^{\mathrm{b}}$ & $1.94^{\mathrm{b}}$ & $1.91^{\mathrm{b}}$ & $2.30^{\mathrm{a}}$ & $*$ & 0.112 \\
\hline
\end{tabular}

${ }^{1} \mathrm{NE}_{\mathrm{L}}$ : Net energy for lactation; $\uparrow, \mathrm{P}<0.1 ; * \mathrm{P}<0.05 ; * * \mathrm{P}<0.01 ; * * * \mathrm{P}<0.001$

Feeding of the alpine hay, representing a typical alpine forage quality (Leiber et al., 2004a), reduced milk fat proportions of C6:0 to C14:0 (Table 2). This is probably related to the lower energy and very low protein supply from this hay, suspected to impair ruminal bioactivity and thus acetate synthesis. The moderately increased proportions of MUFA and PUFA when alpine hay was fed were partially a result of the decrease in SFA. The far lower input of C18:3n-3 with alpine hay than with lowland hay did not result in a decrease of $\mathrm{C} 18: 3 \mathrm{n}-3$ proportions in fat or milk. This lack of relation between C18:3n-3 intake and mammary secretion was also observed on pasture (Leiber et al., 2004b). Obviously, a high C18:3 supply from alpine forages is not responsible for the high n-3 PUFA contents of alpine milk products. One factor which could have caused the increased milk n-3 PUFA is the preferential mobilization of C18:3n-3 as a consequence of the metabolic energy deficit (Soppela et al., 2002) which occurred when feeding only hay. Another factor could have been an increased bypass of C18:3n-3 through the rumen if the dietary energy deficit would restrict ruminal biohydrogenation. 
Table 2. Intake and milk fatty acid profile as affected by hay type ( $n=27$ per hay type)

\begin{tabular}{|c|c|c|c|c|}
\hline & \multicolumn{2}{|c|}{ Origin of the hay fed } & \multirow{2}{*}{ Significance } & \multirow{2}{*}{$\mathrm{SE}$} \\
\hline & $2000 \mathrm{~m}$ a.s.l. & $400 \mathrm{~m}$ a.s.l. & & \\
\hline \multicolumn{5}{|l|}{ Intake } \\
\hline $\mathrm{NE}_{\mathrm{L}}{ }^{1}, \mathrm{MJ} /$ day & 84.4 & 99.6 & $* * *$ & 1.90 \\
\hline C18:3n-3, g/day & 58.3 & 120.1 & $* * *$ & 1.94 \\
\hline total FAME, $\mathrm{g} / \mathrm{L}$ milk & 40.9 & 39.4 & $\dagger$ & 0.78 \\
\hline \multicolumn{5}{|l|}{ FAME composition, $\%$} \\
\hline $\mathrm{C} 4: 0$ & 3.24 & 3.10 & $*$ & 0.055 \\
\hline C6:0 & 2.13 & 2.25 & $*$ & 0.043 \\
\hline $\mathrm{C} 8: 0$ & 1.14 & 1.33 & $* * *$ & 0.029 \\
\hline $\mathrm{C} 10: 0$ & 2.42 & 3.08 & $* * *$ & 0.082 \\
\hline $\mathrm{C} 12: 0$ & 2.78 & 3.66 & $* * *$ & 0.106 \\
\hline $\mathrm{C} 14: 0$ & 10.9 & 12.5 & $* * *$ & 0.29 \\
\hline $\mathrm{C} 16: 0$ & 34.1 & 34.7 & ns & 0.72 \\
\hline C18:0 & 7.57 & 7.49 & ns & 0.287 \\
\hline $\mathrm{C} 18: 1 t 10 / t 11$ & 1.64 & 1.42 & $* * *$ & 0.049 \\
\hline $\mathrm{C} 18: 1 c 9$ & 19.0 & 15.6 & $* * *$ & 0.82 \\
\hline $\mathrm{C} 18: 3 c 9 c 12 c 15$ & 1.22 & 1.18 & ns & 0.036 \\
\hline $\mathrm{C} 18: 2 c 9 t 11$ & 0.82 & 0.76 & $*$ & 0.024 \\
\hline$C 20: 3 n-3$ & 0.119 & 0.108 & ns & 0.0066 \\
\hline$C 20: 5 n-3$ & 0.102 & 0.110 & ns & 0.0043 \\
\hline$C 22: 5 n-3$ & 0.117 & 0.103 & $* * *$ & 0.0039 \\
\hline$\sum n-3$ & 1.95 & 1.83 & $* *$ & 0.046 \\
\hline$\sum \mathrm{n}-6$ & 2.02 & 1.80 & $*$ & 0.078 \\
\hline
\end{tabular}

${ }^{1} \mathrm{NE}_{\mathrm{L}}$ : Net energy for lactation; $\uparrow, \mathrm{P}<0.1 ; * \mathrm{P}<0.05 ; * * \mathrm{P}<0.01 ; * * * \mathrm{P}<0.001$

\section{CONCLUSIONS}

The results demonstrate that neither hypoxia nor a specific fatty acid profile of the alpine forage are primarily responsible for the fatty acid profile of alpine milk. Our results rather suggest that diet type and lack of dietary energy cause the changes in fatty acid profile by influencing different metabolic pathways.

\section{REFERENCES}

Hauswirth C.B., Scheeder M.R.L., Beer J.H., 2004. High omega-3 fatty acid content in alpine cheese - The basis for an alpine paradox. Circulation 109, 103-107

Kraft J., Collomb M., Möckel P., Sieber R., Jahreis G., 2003. Differences in CLA isomer distribution of cow's milk lipids. Lipids 38, 657-664

Leiber F., Kreuzer M., Jörg B., Leuenberger H., Wettstein H.-R., 2004a. Contribution of altitude and alpine origin of forage to the influence of alpine sojourn of cows on intake, nitrogen conversion, metabolic stress and milk synthesis. Anim. Sci. 78, 451-466

Leiber F., Wettstein H.-R., Nigg D., Kreuzer M., Scheeder M.R.L., 2004b. Dietetically relevant PUFA in the milk of cows grazing pastures at different altitudes. Grassl. Sci. Eur. 9, 1139-1141

Soppela P., Nieminen M., 2002. Effect of moderate wintertime undernutrition on fatty acid composition of adipose tissues of reindeer. Comp. Biochem. Physiol. Pt A 132, 403-409 